DOI 10.52363/2414-5866-2021-1-5

УДК 351.72;378.3:336;746.1

Chumak O., PhD in Economics, Associate Professor, Associate Professor of Finance, Banking and Insurance Business department, Interregional Academy of

Personnel Management «IAPM», Kyiv, ORCID ID 0000-0001-6387-2840,

Savchenko I., Ph.D. in Public Administration, Assoc. Prof., Associate Professor of the Marketing, Management and Trade Entrepreneurship Department KITE KNUTE, Kharkiv, ORCID ID 0000-0002-4042-6458

Чумак О.В., д.е.н., дои., ПрАТ «ВНЗ «Міжрегіональна академія управління персоналом», м. Київ,

Савченко І.Г., к.держ.упр., ХТЕI КНТЕУ, м. Харків

\title{
CONCEPTS OF FUNDING PREPARATION OF HIGHER EDUCATION APPLICANTS IN THE CONTEXT OF THE STATE SOCIAL SECURITY
}

\section{КОНЦЕПЦІЇ ФІНАНСУВАННЯ ПІДГОТОВКИ ЗДОБУВАЧІВ ВИ- ЩОЇ ОСВІТИ В КОНТЕКСТІ СОЦАЛЬНОЇ БЕЗПЕКИ ДЕРЖАВИ}

The article analyzes the domestic and foreign experience of higher education funding. The basic principles and mechanisms of public administration funding of higher education institutions are outlined. The main components of the recommended three-component model of funding in the framework of higher education reform are identified, as well as the conditions and positive consequences of implementation of this model in Ukraine.

Keywords: mechanisms of public administration, state social security, funding, higher education, model of funding, income.

Target setting. Within the conditions of the deep transformation processes taking place in the country, special attention is paid to the problem of social security, which directly affects the effectiveness of changes in all spheres of public life. Global Sustainable Development Goals have intensified national states for their adoption and implementation. Ukraine has adapted them to national conditions and committed itself to achieving the National Sustainable Development Goals by 2030. Experts estimate the importance of priority areas and measures to promote sustainable development and enhance social, economic and environmental security. Ensuring educational security at the proper level is a guarantor of independence of Ukraine, a condition for its sustainable development and for increasing the well-being of citizens. In order to implement the ideas of national interests, functioning of the education system should 
be necessarily taken to a qualitatively new level, since education is the foundation of knowledge and intellectual capital formation, which is one of the priority directions for ensuring national security of Ukraine. The current stage of systemic change in society and the reform of public administration in the direction of decentralization requires scientists and practitioners to pay considerable attention to the issues of optimizing the distribution of powers, including financial support for the education sector. Higher education should be considered a multidimensional area that includes economic, social, public and security components. Under the conditions of education reform in Ukraine, it is time to solve the problems of formation and implementation of the state and non-state mechanism of funding the preparation of higher education applicants, as one of the directions of state policy.

Considering the existing system of funding, the level of quality received by the applicants of education, disproportionality in funding by different specialties, sectoral deformation of higher education, unreasonable funding in the context of educational institutions and specialties, lack of a mechanism for effective control spent on training of the education applicants, systems of funding higher education should be improved. At the same time, the existence of public order of specialists in higher education institutions, funding based on the model of estimates, incomplete transparency of deductions on received budgetary funds, and other financial conditions that do not determine the quality of education and do not provide effective control over the provision of services of educational institutions, require significant changes in the funding mechanism in higher education.

Today, there is a situation of disproportionate distribution of funds for the training of specialists in different industries and specialties in the context of higher education institutions, which does not have full grounds, therefore it does not always provide the expected level of quality and efficiency of the resources consumed accordingly. Thus, at the moment the system of funding educational institutions does not meet the up-to-date requirements and certain standards of the existing legislation in the field of higher education, moreover it does not contribute to the achievement of the goals set before the educational institutions for the training of specialists and does not provide for covering the expenses necessary to perform the relevant functions, which actualizes the subject of the chosen direction of the research.

Analysis of Recent Researches and Publications. The issue of funding educational institutions and training of higher education applicants has received considerable attention from state authorities, scientific institutions and higher education institutions. For example, the team of scientists of the Academy of Educational Sciences of Ukraine has been investigating the problems of forming an updated mechanism for funding the higher education system for a long time: V. Lugoviy, I. Gryshchenko, S. Kalashnikova, Yu. Vitrenko, O. Vorobyova, O. Slyusarenko and others. Much attention is paid to reformation in the system of funding higher education at the state level: L. Grinevich, O. Sharov, Yu. Spivakovskiy and others. Local scientists are increasingly paying attention to improving the mechanism of funding higher education: V. Kremen, V. Bakhrushin, T. Efimenko, J. Talanova, T. Bogolib, O. Spivakovskiy, 32 
A. Kasich, V. Malyshko, O. Otkalenko, E. Stadniy and others.

The purpose of the article is to determine the key principles of the prospective concept of state administration of the mechanism of funding the training of higher education applicants in Ukraine in accordance with the chosen reform vectors for national security.

Outline of the main material. In the report at the conference European Integration of Higher Education of Ukraine in the Context of the Bologna Process, O.I Sharov noted that at present there is an archaic concept of public order that requires the introduction of a modern formulaic approach that will orient higher education institutions to achievement [1]. In addition, he noted that as of November 2016 academic autonomy is realized by almost $75 \%$, scientific - by $20 \%$, administrative by $80 \%$, and financial - barely reaches $5 \%$, which indicates the loss of effectiveness of the current model of state funding of higher education in Ukraine. Analyzing the state and conditions of financial support for the functioning of the higher education system in Ukraine, it can be concluded that there are certain disproportions in the funding this type of economic activity both in terms of attracting financial resources and the process of their allocation [2, p.76], which requires a revision of the list of major financial and economic instruments to stimulate the development of educational activities. Therefore, this situation necessitates the formation of educational policy by means of a new model of funding according to public request, taking into account the best foreign practices.

In the scientific literature, there are several thousands of different model modifications of funding higher education institutions, which differ from one another in the conditions of organization and allocation of financial support depending on the level of autonomy of educational institutions, selection of students, recipients of funding, etc., however, the main investor remains the state [2, p. 78]. So far, the budgets of Ukraine have provided for education expenditures according to the budget classification for higher education funding, so the main source of funding is budgetary funds, and additional sources are mostly tuition fees for providing educational services. Such financial paradigm does not allow full implementation of the directions of higher education reform, in particular with regard to financial autonomy. The concept of financial autonomy through the systematization of parameters that evaluate the financial autonomy of universities was successfully investigated by J. Talanova:

- financial structure (state funding; subsidiary (intermediary) funding bodies (funding of institutions and researches; financial reporting);

- financial capacity (backlogs and proficit (surplus); loans and fundraising; land and buildings ownership.

The main features of financial autonomy of universities in EU countries are identified by the following:

- state funding is allocated on a block-grant basis, which requires a clear focus on the goals and achievement criteria;

- entitling rights to universities to obtain tuition fees; 
- restrictions on the operation of universities in the financial markets;

- the right to own land and buildings by universities is determined by national traditions and accordingly influences the capacity of Higher Education Institution to use land and buildings [3, p.65].

Today, the primary problems of achieving financial autonomy are the independent determination of salaries and the number of employees, the standards of all types of pedagogical workload, the disposal of state funding for student education, the restriction of financial activity standards of the Budget Code and treasury service, the amount of funding does not always depend on the achievements in this direction. To eliminate these problems, a working group of the Ministry of Education and Science has prepared a draft of legislation "On Amendments to the Law of Ukraine" On Higher Education" with respect to Funding Higher Education", which provides that:

1) state and municipal higher education institutions may acquire the status of a non-profit organization;

2) the person can obtain higher education at the expense of the state budget and the local budget at the regional order;

3) people who have received the right to obtain higher education with financial support at the expense of expenditures or local budgets may receive such education under the terms of a preferential loan;

4) the allocation of the state budget funds by the higher education institution is calculated according to the appropriate formula;

5) Higher education institutions independently manage the funds for the preparation of applicants of education within their intended purpose.

Therefore, the implementation of these updated standards of legislation necessitates the application of new approaches to funding higher education, in particular those that have gained positive practice in foreign countries. T. Efimenko also points out that in Ukraine it is necessary to improve the scientific and methodological foundations of the resource availability of research on the basis of quantitative and qualitative assessment of their effectiveness according to the principles and methods of the best international experience, to carry out reliable and objective monitoring of the processes of creation and implementation of a scientific product [4, p.13]. However, improvements need to be introduced by means of both funding scientific researches and educational programs. In this aspect, the experience of European countries is valuable, which defines the overall strategy for funding higher education in accordance with the state development strategy and state funding which is based on the achieved goals and the accomplished work. This approach is based on the idea of combining the goals of governments and the goals of universities (education and science). At the same time, Yu.Vitrenko points out that in Ukraine there is practically no officially established conceptual and categorical apparatus for strategic planning of higher education [5, p. 55]. Therefore, at the time the existing and introduced new concepts in this field are being clarified at the legislative level, which should be the basis for defining the strategic goals of educational development. In the monograph of the team of authors [2, p.79] the models of funding educational activity are grouped into three types 34 
according to the source [6]: (1) the model of funding education focused on the free market which provides for decentralized management of educational institution both in terms of scientific and educational activity, and in terms of attraction financial resources and defining the proportions and directions of their distribution, while minimizing state expenditures to perform educational activity (neoliberal policy of funding by M. Friedman, F. A. Hayek); (2) a model of funding education, focused on the public market with the active participation of the state in the development of the national education system, including its funding (D. Shumpeter, N. Kondratiev); (3) a model of social funding education, focused on alternative integrated society, under which the government should take full responsibility for the development of the education system, funding.

Based on the study of publications on the system of funding institutions of higher education in the USA, it can be stated that:

1 . The system of funding is determined by the type of higher educational institution and the education policy of the state.

2. The income of educational institutions can be broadly classified according to the sources of their receipt in the following way: budget (state and local), tuition fees paid by private (legal) entities, loans, other income, grants and charity assistance.

In many countries, funding education from the budget is implemented at the level between $60 \%$ and $80 \%$. Upon that, the part of the funds will be sent from the state budget, part from the local (state, federation) as agreed by the government. Funding depends on the result of the activity (accordingly, there is a need to determine the criteria by which the result should be evaluated) and on the basic needs of the institution. Tuition fee is on average $40 \%$ of revenues (in public institutions). However, there is a number of programs for varying the amount of tuition (flexible system of discounts, fee waivers, single support at the admission, etc.) that allow students from low-income families to gain higher education. Loans are allocated from the budget (at all levels) or banking institutions on the following conditions: paying back upon graduation at a percentage which is the part of the National Bank rate, with partial repayment after the first year of study, private (applicable in case there is a need to refund the difference between the real cost of study and government loan).

Technical parks are being created as well as more complex structures to ensure the integration of science with business (it is possible to start a "pilot" project in the same higher educational institution with the state support at the first stage of creation, or to start the gradual introduction of separate structures). In the USA scientific products are transferred to consumers (government, manufacturing plants) by means of these parks on the world market.

3. During funding, some foreign countries refuse to make estimates, applying the principle of budgeting, which allows them to be guided by the results of activities within the framework of the execution of the state task and the state contract.

Ukraine should consider the experience of financial support of the highest US university capacity by means of an endowment mechanism, which in 2015 accounted for $85 \%$ in 13 out of 22 private US higher education institutions that are ranked from 
$1^{\text {st }}$ to $30^{\text {th }}$ in the Shanghai rating [7, p.16]. Based on the investigated literature sources [8; 9 and others], several approaches to funding higher education applicable by foreign countries are highlighted:

- expenditure funding (Canada, United Kingdom, France, Japan, Sweden, Norway, China) means that budgetary funds go directly to universities, and their use is clearly controlled by the government;

- funding based on results (Denmark, Finland, Israel, Netherlands, USA, Croatia, etc.) means that the allocation of public funds depends on direct (quality and volume of educational services) and final (socially-economic effect of education) results of educational and research activities of higher education institutions;

- contractual funding of education (Brazil, Argentina, India, Greece, Italy) is based on the results of negotiations between higher education institutions and the education ministry or financial institutions.

The diversification of higher education funding has positive tendency in Latvia, where a competitive budget is drawn up according to the objectives set by the government whereas performance is assessed on a model that takes into account the incentives for the education system. In Croatia and other European countries together with the system based on the performance measure the Ministry of Education and a higher education institution concludes a contract, which specifies a system of educational quality indicators that in some way relate to local programs (needs of the region). When a university fulfills its contractual performance obligations, the university may receive additional funding from a national or local budget.

I. Svityashchuk outlines three general approaches to funding higher education in some European countries [10, p.30]:

1. Poland - Block grant. There is no restriction on the use of the educational part of the amount, however the funds for research are directed explicitly to specific faculties.

2. France - Block grant is divided into different categories of destination. Funds cannot be transferred from one group of expenses to another one.

3. England, Netherlands, Finland - Block grant. The university takes full responsibility to make a decision how to spend the received money.

Thus, as a result of our research, key levels of funding have been outlined which recommend funding higher education applicants in Ukraine:

1. Funding education at the expense of the state and local budgets of applicants who are striving for preparing for professional careers that ensure the fulfillment the basic functions by the state which are envisaged by the Constitution of Ukraine (education and health care and defense and security of the state).

2. Funding the training of the applicants at the expense of state-owned enterprises (or its share of more than 25\%), which is attributed by the government to priority sectors of the economy (the need for a regulatory document). In this case, the tuition fee and scholarship support are supposed to be included in expenses in the bookkeeping and tax accounting. Conditions of working off and compensation of sums in case the applicant does not work off are equal to such conditions when stu36 
dents gain higher education by public order.

3. Funding higher education applicants at the expense of a preferential loan obtained by an applicant at a commercial bank with full or partial repayment of interest on the loan at the expense of the state or local budgets. It is advisable to develop a mechanism whereby the loan cannot be repaid with the maximum risk mitigation and the need for electronic compensation for the financial year. Getting a loan can also be considered as a part of the education funding.

4. Students who enter a higher education institution may apply for scholarships and grants to study from public and private funds, organizations and programs which are targeted funding that is competitively obtained. Allocating the scholarship should be based on the analysis of the student's needs and their success (educational and scientific). Scholarships should be considered as repayable or non-repayable financial assistance (for example, working in public sector for over five years).

5. Funding higher education applicants at the expense of private and/or legal entities. Provide scholarships for successful students.

6. Attraction of financial resources from other sources.

$\mathrm{V}$. Kovtunets notes that it is advisable to allow universities to determine on their own what kind of specialists the budget funds need to be directed within the licensed volume. Under such conditions, state funding training should be unit-type, and its volume can be calculated according to a certain formula [5, p.103]. T. Bogolib recommends expanding the diversification of funding sources and introducing a binary funding system in the following areas: involvement of employers and entrepreneurs in the funding of education; optimization of public order; capitalization in higher education; transition to project and program-targeted funding of education and public-private partnership [11, p.5]. Authors of the monograph [2, p.82] consider the development and implementation of progressive methods of funding educational activities, including the implementation at the national level of a single unified model of funding a higher education institution, which will have the following components: (1) financial support for the education of a student; (2) scholarship of a student on a grant (competitive) basis; (3) infrastructure development (training and production equipment of library stock, etc.); (4) financial support for research activities of lecturers and students.

The change in the model of funding higher education is aimed at introducing a three-component model, which includes: basic funding (abroad up to $80 \%$ of total income), performance-based funding up to $15 \%$ ) and other revenues (up to 5\%). Gradual transition of Ukraine to a performance-based funding approach, as the second component in the higher education funding model, provides opportunities to:

- to receive funds for specific researches;

- to receive funding after obtaining the result specified in the agreement;

- funds repayment by the university or deduction of a certain amount from future planned financial requests, in case of failure to fulfill the terms of the contract;

- encouraging the government to diversify its sources of funding;

- organizational capacity expansion with employers (by means of specialist or- 
ders);

- establishment of a reserve fund (monthly or annual payments) by universities for spending on priority needs;

- directing the state funds for training specialists in certain specialties;

- provide for a mandatory system of indicators in contracts, some of which should be used only for selected universities;

- attracting charitable contributions for which the university should ensure transparency and control, etc.

Without reforming and expansion of the educational sector, it is impossible to implement the process of actual state building. Insufficient attention to education threatens the national security of the country. In fact, whatever national security components would be taken which can be economic, political, military, energy, information or environmental, we need highly qualified specialists everywhere, whose lack endangers exactly the existence of the state.

Conclusions. Summarizing the results of the research, it should be noted that the significant scope of human, material and financial resources involved in the education sector, the role of education in social and economic development lead to an indepth study of the scope and results of educational activities and the effective use of these resources. Therefore, education is a pledge of the future of the country, an important component of its national security. When reforming the mechanism of funding higher education, two general approaches should be envisaged in the state funding of higher education: the state finances of educational institutions and/or applicants of education. The solution today requires the development of a financial mechanism for basic funding schools and the definition of a system of criteria or indicators for performance-based funding. Within the framework of financial autonomy, the definition and legislative provision of the most accessible and popular other sources of funding becomes relevant.

The role of the state in funding should be introduced in such mechanism of public administration as the evaluation of higher education institutions by the results of their work (educational, organizational, scientific) on the basis of competition, and the assessment of the skills of the education applicants after graduation should be the key factor. At the same time, the fulfillment of the social function of the state, as one of the national security functions in the field of higher education, must be constantly followed (education applicants are people who temporarily moved to another place, privileged citizens, regional criterion, etc.). Therefore, the state funding of higher education should take into account the support for the development of promising sectors of the economy, stimulating universities to competition, planning future activities of higher education institutions.

\section{References:}

1. Sharov O.I. (2016) Perspekty'vy' finansovoyi avtonomiyi universy`tetiv Ukrayiny'. Yevropejs `ka integraciya vy'shhoyi osvity`Ukrayiny`v konteksti Bolons `kogo procesu, [Prospects for financial autonomy of Ukrainian universities]. Proceedings of the V 
International scientific-practice conferences, 23/11/2016 r. Kyiv: 4-8 [in Ukrainian].

2. Teorety`ko-metodologichne obg`runtuvannya efekty`vny`x finansovoekonomichny`x modelej rozvy`tku vy`shhoyi shkoly` [Theoretical and Methodological Substantiation of Effective Financial and Economic Models of Higher Education Development]. I.M. Gry`shhenko (Ed.). Kyiv [in Ukrainian].

3. Vorobjova O.P., Gorecz`ka T.O., Dem'yanenko N.M., Kalashnikova S.A., Kovalenko O.M., Lugovy`j V.I., Sy`ch O.K., Slyusarenko O.M., Talanova Zh.V., Tkachenko V.P. (2015). Avtonomiya ta vryaduvannya u vy`shhij osviti. Kyiv. [Autonomy and governance in higher education]. [in Ukrainian]

4. Yefimenko T. (2016). Konceptual'ni pidxody' do rozvy`tku mexanizmiv finansuvannya nauky` [Conceptual approaches to the development of financing mechanisms for science]. Finansy`Ukrayiny` issue 8, 9-23 [in Ukrainian].

5. V. Kovtunecz' (2015). Aktual’ni problemy` ekonomichny`x vidnosy`n u sferi vy`shhoyi osvity` Ukrayiny` ta osnovni napryamy`yix rozv'yazannya [Actual problems of economic relations in the field of higher education of Ukraine and the main directions of their solution]. Kyiv [in Ukrainian].

6. Hofman Hans Georg. (2000). Novie formy fy`nansy`rovany`ya, garanty`ruyushhy`e ravnoe obrazovany`e dlya vsex, y` razvy`ty`e sy`stemy platnogo obrazovany ya. [New forms of financing guaranteeing equal education for all and the development of a fee-paying education system].Uny`versy`tetskoe upravleny'e: prakty'ka y` analy`z. 4(15). 35-42. URL: http://ecsocman.hse.ru/univman/ [in Russian].

7. Lugovy`j V.I. (2015) Mexanizmy` finansuvannya doslidny`cz’ko-innovacijnoyi diyal'nosti universy`tetiv u SShA. [Funding mechanisms for research and innovation of universities in the United States]. Efekty 'vnist' organizacijno-ekonomichnogo mexanizmu innovacijnogo rozvy'tku vy'shhoyi osvity' Ukrayiny`. Special issue on material V international. scientific-practical conference, 2 zhovt. 2015 r. Kyiv: Visny`k KNUTD. Seriya Ekonomichni nauky', 5-20 [in Ukrainian].

8. Shevchenko L. S. (2013). Finansuvannya vy`shhoyi osvity`: dy`versy`fikaciya dzherel. [Financing higher education: diversification of sources]. Teoriya $i$ prakty $k a$ pravoznavstva - State Formation, 2. URL: http://nbuv.gov.ua/UJRN/tipp_2013_2_44_[in Ukrainian].

9. Maly`shko V. V. (2016). Finansuvannya vy`shhoyi osvity`v Ukrayini: problemy` ta perspekty vy'. [Higher Education Financing in Ukraine: Problems and Prospects]. Molody`j vcheny`j. issue 2 (29), 64-67 [in Ukrainian].

10. Svityashhuk I., Solod ko A, Stadny`j Ye. (2014). Derzhavne finansuvannya pidgotovky` kadriv u vy`shhij osviti: dosvid ta vy`kly`ky`. [Public funding for training in higher education: experience and challenges]. Centr vidrodzhennya suspil`stva. [in Ukrainian].

11. Bogolib T. (2015). Finansove zabezpechennya osvitn`oyi galuzi Ukrayiny`: isnuyuchi problemy` ta perspekty`vy` yix vy`rishennya [Financial support of the Ukrainian educational sector: existing problems and perspectives for their solution]. Ekonomist issue 8, 1-6. [in Ukrainian]. 